\title{
Indigenous Tribes in Brazil and the Increasing Attack from Business Interests
}

\section{DESTINY MUGASHA KEBIRUNGI ${ }^{1}$ - ALEX FORSTER $^{2}$ - ERIN WATKINSON ${ }^{3}$}

\begin{abstract}
The article offers an overview of the evolution of Brazilian law in relation to the living descendants of indigenous people who lived on the territory of Brazil before Portuguese colonisation. The legal developments reflect the evolution of the relation between the Brazilian state and the indigenous peoples since Brazil gained independence. This short article also offers a look at the implementation of relevant international norms on the rights of indigenous peoples in the Brazilian context.
\end{abstract}

Keywords: indigenous people's rights, Brazil, constitutional law, international law

\section{Introduction}

The focus of our analysis is on the living descendants of indigenous Brazilians, referred to as 'Indians' in Brazilian law, from tribes that existed prior to Portuguese colonisation in 1500. In 1500, a broad estimate of the number of indigenous Brazilians would be in the order of millions, spread across thousands of tribes. ${ }^{4}$ Of course, it is impossible to give any kind of exact figure, as this significantly pre-dates any kind of census information. In contrast, the 900,000 or so indigenous Brazilians recorded in the 2010 census offers some insight into the demographic trends. ${ }^{5}$ Whilst this figure is significantly more exact, it is worth noting that numbers will vary somewhat according to the group gathering the data. This article will discuss the relationship of the Brazilian state with indigenous groups since independence. It will analyse the role of

1 Destiny Mugasha Kebirungi, postgraduate student, Law School, University of Liverpool, e-mail:dkmugahsha@gmail.com

2 Alex Forster, postgraduate student, Law School, University of Liverpool

3 Erin Watkinson, postgraduate student, Law School, University of Liverpool

4 RV Santos et al., 'The identification of the Indigenous population in Brazil's official statistics, with an emphasis on demographic censuses', Statistical Journal of the IAOS 35, no 1 (2019), 29-46.

Ibid. 
soft law instruments, ILO Convention No. $169^{6}$ and also the UN Declaration on the Rights of Indigenous Peoples (henceforth: the Declaration). ${ }^{7}$ It will also discuss the role of customary international law, by analysing the role of the Inter-American Court of Human Rights (henceforth: IACtHR), and argue whether the current provisions in place are sufficient enough to protect indigenous tribes in Brazil from the increasing attack from business interests.

\section{The relationship of the Brazilian state with indigenous tribes since independence}

Indigenous tribes occupy a number of demarcated territories, amounting to 115 million hectares across Brazil. ${ }^{8}$ Around half of the indigenous population live within legal Amazonia, though this represents 98.5 per cent of the land by area. ${ }^{9}$ The Amazon is well-known as the site of abundant natural resources, including lumber and mineral resources. Meanwhile, Brazil's large and influential beef industry has been growing for decades into what is now the single largest global producer, driving demand for land. ${ }^{10}$ These economic interests appear to have converged on the Amazon and indigenous lands, leading to anxiety and public campaigns to uphold the existing legal protections. ${ }^{11}$

Taking a wider view for the time being, it is possible to identify three general periods in the government's approach to tribal issues in Brazil. These could have been divided in a number of ways, but here the aim is to give insight into broad trends, rather than a comprehensive breakdown of historic government policies. The periods identified here are:

- Independence - 1988 Constitution;

- 1988 Constitution - the collapse of Dilma Rousseff's Government;

- Collapse of Dilma Rousseff's Government - Present.

Each period has a respective theme. First, the gradual and hard-won battle for legal protections for indigenous peoples and associated territories. This was followed by a period of rapid development to a minority rights regime that has been widely praised as world leading. Finally, the wholesale change in political environment that has led to constitutional realignment and pledges to dismantle protections.

6 International Labour Organization (ILO), Indigenous People and Tribal Peoples Convention (adopted June 27, 1989, entered into force September 5, 1991). C169.

7 UN General Assembly, United Nations Declaration on the Rights of Indigenous Peoples, (adopted October 2, 2007). A/RES/61/295.

8 Santos et al., 'The identification', 31.

9 Ibid.

10 GB Martha Jr, E Alves and E Contini, 'Land-saving approaches and beef production growth in Brazil', Agricultural Systems 110 (2012), 173.

11 D Phillips, 'Brazil: Indigenous people rally in capital to protest against Bolsonaro onslaught', The Guardian, April 24, 2019. 


\subsection{From independence to the 1988 Constitution}

Brazil gained its independence from Portugal in 1822. Since the arrival of the colonists, the indigenous population had significantly reduced and relocated, with surviving tribes forced away from coastal mining areas and seeking refuge from violence deeper in the Amazon. ${ }^{12}$ Independence resulted in little immediate change for these peoples. Pedro I stayed on as Emperor of the former colony, whilst most of the other royals returned to Portugal. ${ }^{13}$ Exploitation of the large and mixed population remained the bedrock of the Brazilian economy, becoming the last nation in the Americas to abolish slavery, almost four centuries after the trans-Atlantic slave trade. ${ }^{14}$

Even after these changes did take place, violence towards tribes continued well into the $20^{\text {th }}$ century. If they lived on a territory that were deemed economically exploitable, as the Guarani did in the 1940s, they were dislodged and forced into smaller settlements. ${ }^{15}$ Crimes against others were more egregious still, as 87 tribes were entirely lost between 1900 and 1957 due to a combination of violence and the introduction of unfamiliar diseases. ${ }^{16}$ In terms of lived experience, the creation of the Brazilian state plainly reflected Portuguese colonisation. Indigenous peoples were at best considered a nuisance and impediment to economic development, and at worst savages that were deemed inferior and worthy of extinction.

However, in response to the violence both perpetrated and effectively sanctioned by the state, indigenous rights groups emerged to offer support and lobby for protections. Many of these groups were Christian missionaries, aiming to spread religious messages amongst Amazonian peoples whilst offering assistance. ${ }^{17}$ Assimilationist policy was also the approach taken by governments when measures were taken to protect tribes in the $20^{\text {th }}$ century. It was hoped that more developed Brazilians would be able to supervise the intellectual and cultural maturation of the 'childhood of humanity'. ${ }^{18}$ For the majority of this initial period, the few efforts made to help indigenous peoples were motivated by the desire to bring an end to their way of life and unilaterally integrate them into majority Brazilian society. It was only by the 1970s that a wave of activist-scholars set the groundwork for what is now recognised as a modern, multiculturalist approach. Efforts to politically organise tribes around the premise that theirs was a distinct culture deserving of protection and rights set the stage for the next period in Brazil's relationship with its native peoples.

12 Y Miki, Frontiers of Citizenship: A Black and Indigenous History of Postcolonial Brazil (Cambridge: Cambridge University Press, 2018), 2.

13 Ibid. 4.

14 Ibid.

15 MC Cunha et al., 'Indigenous Peoples boxed in by Brazil's political crisis', HAU Journal of Ethnographic Theory 7, no 2 (2017), 404.

16 P Calafate, 'The Rights of the Indigenous Peoples of Brazil: Historical Development and Constitutional Acknowledgment', International Journal on Minority and Group Rights 25, no 2 (2018), 207.

17 Santos et al., 'The identification', 34.

18 Ibid. 30. 


\subsection{From the 1988 Constitution to the collapse of Dilma Rousseff's government}

The latter half of the 1980s marked a radical change for Brazilian politics and society. 1985 saw the fall of the military dictatorship that had led the country for the last 20 years, ultimately resulting in the 1988 Constitution. ${ }^{19}$ Along with the strengthening of democratic institutions, it also codified the abandonment of state guardianship and assimilationist policies for indigenous tribes, adopting many of the policy recommendations of multiculturalist scholars that had come to prominence in the previous decade. ${ }^{20}$ Autonomy was increased, giving tribes far more input on the decisions made over their lands - although the ultimate sovereignty still lies with the Brazilian state. ${ }^{21}$ A specific agency, The National Indian Foundation (FUNAI), was created in order to oversee, centralise and formalise the assistance provided to indigenous groups. However, it is notable that much of the practical work continued to be conducted by evangelist groups. ${ }^{22}$ These efforts for indigenous Brazilians and a broader focus on individual rights led to the popular nickname 'Citizen Constitution, receiving praise as the foundations for a future multiculturalist society that would integrate all peoples with respect for the individual cultural differences. ${ }^{23}$

\subsection{From the collapse of Dilma Youseff's government to the present}

The ensuing two decades saw indigenous rights stronger than they had ever been in Brazil, albeit still with significant flaws. Through the 1990s it was observed that autonomy of political leadership was not a viable option, so tribes had to rely on white NGOs to gain access to political and economic channels. ${ }^{24}$ Effective requirement of 'private wardship' did undermine the strength of the process, despite practical gains. ${ }^{25}$ It is fair to describe this period as one of 'imperfect yet significant' progress in the codification of indigenous rights, as the majority of territories were demarcated and consecutive governments would continue this course of policy. ${ }^{26}$ This period came to an end in 2016. President Dilma Rousseff was impeached by the Senate on August 31, coming on the back of a corruption scandal that had implicated much of the political class, in the context of Brazil's greatest economic slump in decades.$^{27}$ Brazil's

19 JRS Pinto, 'The legislative and public policies in Brazil: before and after the 1988 Constitution', Journal of Legislative Studies 22, no 4 (2016), 484.

20 Santos et al., 'The identification', 31.

21 Ibid. 32.

22 Ibid. 34.

23 Cunha et al., 'Indigenous Peoples', 404.

24 AR Ramos, 'The Indigenous Movement in Brazil: A Quarter Century of Ups and Downs', Cultural Survival Quarterly 21, no 2 (1997), 50.

25 Ibid. 53.

26 L Valenta, 'Disconnect: The 1988 Brazilian Constitution, Customary International Law, and Indigenous Land Rights in Northern Brazil,' Texas International Law Journal 38, no 3 (2003), 643.

27 J Watts, 'Dilma Rousseff impeachment: what you need to know - the Guardian briefing', The Guardian, August 31, 2016. 
Senate voting for impeachment brought an end to 13 years of Workers' Party rule and was a major victory for the agribusiness lobby, having previously struggled in a system in which the balance of power still significantly favoured the executive over the legislature. ${ }^{28}$ Rousseff was succeeded by her Vice President, Michel Temer, of the Brazilian Democratic Movement Party.

Moving into the final period, the political crisis created the circumstances for the attempted dismantlement of the indigenous rights regime. President Temer was also implicated in the corruption scandal, meaning that his ability to govern depended on the Senate keeping him in place. ${ }^{29}$ The agribusiness lobby, which had been longtime opponents of the strong land rights that inhibited the economic development of tribal land and those that upheld the system, backed Temer through threats of impeachment in return for 'tougher abortion restrictions and looser gun control'. ${ }^{30}$ With the government now effectively in the hands of this lobby, farmers' interests were advanced at the expense of indigenous groups and a leading member went on to state that they would support Temer's economic plan on the basis that the president was a Christian who believes in marriage between a man and a woman. ${ }^{31}$ Such leverage over a president was unprecedented, and it started the erosion of human rights and conservation laws in the 28 months he was in power. ${ }^{32}$

2018 ended with the election of Jair Bolsonaro, a long-time Congressman with strong ties to the agribusiness lobby. His first measure on January 1, 2019 was to begin dismantling FUNAI, aiming to take it out of a human rights ministry and place it in the Agriculture Ministry that was controlled by farming interests. ${ }^{33}$ Headed by an evangelical pastor whose group has worked in indigenous communities, the decision was met with consternation by staff of the agency and has been perceived as a sign of the move away from a multiculturalist approach. ${ }^{34}$ Fears were only compounded by Bolsonaro's previous statements as a senator, when he was quoted as regretting 'that the Brazilian cavalry wasn't as efficient as the Americans, who exterminated the Indians. ${ }^{35}$ Rhetoric and policy have aligned against indigenous peoples under the Bolsonaro government, and it is in this context that violence against these groups has increased from loggers, miners and ranchers wishing to exploit demarcated land. ${ }^{36}$

28 Ibid.

29 A Boadle, 'Brazil's Bible, beef and bullets lobby backs Temer, unfazed by scandal', Reuters, June 24, 2016.

30 Ibid.

31 Ibid.

32 Cunha et al., 'Indigenous Peoples'.

33 D Phillips, ‘»We are fighting «: Brazil's indigenous groups unite to protect their land', The Guardian, March 4, 2019.

34 D Phillips, 'Bolsonaro to abolish human rights ministry in favour of family values', The Guardian, December 10, 2018.

35 F Watson, 'The uncontacted tribes of Brazil face genocide under Jair Bolsonaro', The Guardian, December 31, 2018.

36 S Guajajara, 'The fight to save the Amazon is urgent as there is no Plan B'. Down to Earth, August $28,2019$. 
As fires continue to burn across the Amazon, it appears that the domestic means of conservation that are attached to tribal land are no longer effective and being actively undermined by the state.

\section{The role of the ILO Convention No. 169}

In pursuit of universal social justice, the ILO Convention No.169 has been concerned with the situation of indigenous and tribal peoples virtually since its interception. ${ }^{37}$ Convention No. 169 is based on the obligation to identify and demarcate indigenous and tribal peoples' territories. ${ }^{38}$ Article 14.2 of this Convention states: 'Governments shall take steps as necessary to identify the lands which the peoples concerned traditionally occupy and to guarantee effective protection of their rights of ownership and possession. ${ }^{\prime 39}$ The government has the obligation under Article 6 Sections (1) (a) and (2) of the Convention, to consult the peoples covered by the Convention through their representative institutions. ${ }^{40}$ Furthermore, according to Article 7 Section (3) of the Convention, 'governments shall ensure that studies are carried out in cooperation with the peoples concerned to assess the social, spiritual, cultural and environmental impact on them of planned development activities.41 It is important to note that Convention No.169 is the only international instrument which specifically provides protection for indigenous and tribal peoples. ${ }^{42}$

Convention No. 169 has been taken into account in the interpretation of constitutional norms concerning indigenous tribes in Brazil. ${ }^{43}$ For instance, the Supreme Federal Tribunal explicitly invoked ILO Convention No. 169 when deciding cases relating to property rights of the quilombola communities. ${ }^{44}$ In these cases, 8,713 hectares was cleared for the spaceport in the early 1980s, displacing over 1,500 quilombolas without sufficient land to maintain their livelihood. Sliberling notes that to date, over 160,000 hectares have now been cleared. ${ }^{45}$ Similarly, in the Belo Monte $\mathrm{Dam}^{46}$ case, a report released by the Committee of Experts on the Application of Conventions and Recommendations for the ILO found that the Brazilian government

37 Monitoring Indigenous and Tribal Peoples' Rights through ILO Conventions: A compilation of ILO supervisory bodies' comments 2009-2010, International Labour Organization. 4.

38 Ibid.

39 ILO Convention No. 169 (n 3), Art. 14.2.

40 Ibid.

41 Ibid.

42 C Phuong, The International Protection of Internally Displaced Persons (Cambridge: Cambridge University Press, 2005), 49.

43 MVC Ormaza, The Requirement of Consultation with Indigenous Peoples in the ILO: Between Normative Flexibility and Institutional Rigidity (The Hague: Brill, 2017), 90.

44 Supreme Federal Tribunal of Brazil, Judgement No. 027/2007/JCM/JF/MA (Jurisdicia Federal de 1a Instancia).

45 SL Silberling, 'Displacement and quilombos in Alcantara, Brazil: modernity, identity, and place', International Social Science Journal 55, no 175 (2004), 145-156.

46 Communicades Indigenos da Bacia do Rio Xingu v Brasil (Belo Monte Dam Case). Inter-American Commission on Human Rights Report No 381/10 (I-ACHR, April 1, 2011). 
directly violated the rights of indigenous communities in the Xingu region of the Amazon while moving forward with the controversial Belo Monte Dam project. ${ }^{47}$ The report shows that by failing to conduct indigenous hearings in villages impacted by the Belo Monte Dam prior to approving the project's construction, Brazil violated Convention No. 169 which guarantees indigenous peoples the right to free, prior and informed consultation over projects that affect their lands and rights. ${ }^{48}$ According to the ILO document, 'the Commission notes that, under Article 15 of the Convention, the government is obliged to consult indigenous peoples before undertaking or permitting any programs for the exploitation of existing resources on their lands, going on to state that Belo Monte would change the navigability of the Xingu, while irrevocably impacting the fauna, flora and climate of the region. These impacts, the ILO said, 'go beyond the flooding of land or displacement of these people. ${ }^{49}$

However, there has been little progress in the development of national regulation regarding indigenous tribes in Brazil, despite the fact that the Brazilian Congress ratified the ILO Convention in $2002 .{ }^{50}$ In fact, Tauli-Corpuz observed that until 2016, there was no established mechanism for consultation of indigenous tribes in relation to legislative measures.$^{51}$ For instance, although the official recognition of a quilombo does not usually lead to effective land legalisation, there is no legislation to regularise the rights and territorial space of the quilombolas. ${ }^{52}$ In 2003, CONAQ, in partnership with ACONERUQ and COHRE, established the National Campaign for Land Regularisation of Quilombo Territories and almost five years later, the Campaign ended without achieving its primary objective. ${ }^{53}$

We agree with Demissie who argues that one of the reasons as to why Convention No. 169 is not fully effective is because countries can sign and ratify international conventions but are not obliged to implement or enforce them. ${ }^{54}$

In conclusion, in regard to what steps the ILO Convention No. 169 can take to prevent the threats made by the Bolsonaro government, at the moment nothing can be done, since states have the right to sign and ratify international conventions but are not obliged to implement or enforce them, unless that is enforced by the treaty itself (which does not seem to be the case here). If that does happen, then an alternative legal argument is that the state is still bound by international customary law in certain areas and that, from a human rights law perspective, the existence of

47 Report of the Committee of Experts on the Application of Conventions and Recommendations, International Labour Conference, 98th Session, 2009. 674.

48 'ILO Says Brazil Violated Convention 169 in Belo Monte Case. International Labor Organization Confirms Government Violated Indigenous Rights.' State News Service, March 7, 2012.

49 Ibid.

50 Ormaza, The Requirement, 91.

51 United Nations General Assembly, Report of the Special Rapporteur on the Rights of Indigenous Peoples in her Mission to Brazil, para. 63.

52 F Demissie, African Diaspora in Brazil: History, Culture and Politics (New York: Routledge, 2016), 138.

53 Ibid.

54 Ibid. 
indigenous peoples does not depend on state recognition. This will be discussed in the next chapter.

\section{The role of the UN Declaration on the Rights of Indigenous Peoples}

The UN Declaration on the Rights of Indigenous Peoples and Convention No.169 are mutually reinforcing instruments providing the framework for the universal protection of indigenous and tribal people's rights. This Declaration came into force on December 13, 2007 and 143 countries voted in favour of this, including Brazil. In comparison to the Convention No. 169, the UN Declaration demands free prior and informed consent and not just consultation. ${ }^{55}$ It is therefore arguable that since Brazil voted in favour, then it is bound under customary law due to its practice in favour of, or at least not against the extent of indigenous rights.

\section{Inter-American Court of Human Rights}

The Inter-American Court of Human Rights (IACtHR) is an autonomous judicial institution based in the city of San José, Costa Rica. Together with the Inter-American Commission on Human Rights (IACHR), it makes up the human rights protection system of the Organization of American States (OAS), which serves to uphold and promote basic rights and freedoms in the Americas. It is important to note that this Court rules on whether a State has violated an individual's human rights, rather than if individuals are guilty of human rights violations.

The 'Mayagna (Sumo) Awas Tingni Commmunity v Nicaragua ${ }^{56}$ was a case ruled by the Court and similar to the situation in Brazil, in terms of indigenous peoples' rights and increasing attacks from business interests. This case involved the petition before the IACHR denouncing 'the State of Nicaragua for failing to demarcate the Awas Tingni Community's communal land and to take the necessary measures to protect the community's property rights over its ancestral lands and natural resources.... The IACHR submitted the case to the IACtHR, who concluded that Nicaragua had violated the right to judicial protection and to property, ${ }^{157}$ as a result of the state's failure to 'delimit and demarcate' the lands of the Mayagna (Sumo) Awas Tigni people..$^{58}$ In addition, the IACtHR 'decided that the State had to adopt the necessary measures to create an effective mechanism for demarcation and titling of the indigenous communities' territory, in accordance with their customary law, values' and customs. ${ }^{59}$ The Court also ordered the Nicaraguan government 'to refrain

55 J Hohmann and M Weller (eds.), The UN Declaration on the Rights of Indigenous Peoples: A Commentary (Oxford: Oxford University Press, 2018), 262.

56 Inter-American Court of Human Rights - The Case of the Mayagna (Sumo) Awas Tingni Community v. Nicaragua - Judgment of August 31, 2001.

57 Caselaw database, ESCR-Net.

58 Hohmann and Weller, The UN Declaration, 191.

59 Caselaw database. 
from any acts that might affect the existence, value, use or enjoyment of the property located in the geographic area where the members of the Awas Tingni community live and carry out their activities, ${ }^{160}$ until their lands were demarcated and titled.

This case is of major significance, because it is a leading case in the jurisprudence of the Court on the rights of indigenous peoples to their ancestral land ${ }^{61}$ and is a major step in the fight against the historical and ongoing subjugation of indigenous peoples in the region.

\section{Conclusion}

In conclusion, we have discussed how conflict of interests between the Brazilian government and indigenous peoples has been ongoing before the state of Brazil was formed in 1822. Despite the fact that indigenous peoples were driven into the Amazon as a place for refuge, they have been offered little respite as the 'resource rich' rainforest has now become the next subject for increasing business interests and economic development. The ensuing 150 years have seen regular and massive atrocities committed, either by the state or with its complicit disinterest, as indigenous Brazilians faced displacement or slaughter when their land became sought after for economic exploitation.

A series of hard-fought and gradual victories through the $20^{\text {th }}$ century, emphasising the right of all peoples to live with security for their culture and lifestyle, culminated in the 1988 Constitution, which included a range of provisions to codify these protections. Ensuing decades have seen the adoption of a multiculturalist approach by the state, with strong rights over land and a dedicated ministry to act in the interests of indigenous groups. However, with the collapse of Dilma Rousseff's government, 2016 saw a reversal in this momentum. As the agribusiness lobby became the most powerful group in Brazilian politics, protected lands once again became the focus for companies' seeking to utilise the resources. This lobby consolidated its interests with the 2018 election of Jair Bolsonaro, who immediately set about dismantling and weakening many of the legal measures designed to protect indigenous peoples. At present, the position of indigenous peoples in domestic law and politics appears to be at its weakest since the 1988 Constitution, leading some to turn to international law for help.

Although the ILO Convention No. 169 and the UN Declaration on the Rights of Indigenous Peoples are mutually reinforcing instruments providing the framework for the universal protection of indigenous peoples and tribal people's rights, they are not legally binding in nature. We have also argued that land and natural resources

60 Ibid.

61 Hohmann and Weller, The UN Declaration, 192. 
are crucial for the survival and cultural heritage of indigenous peoples. ${ }^{62}$ Therefore if development projects from business interests emphasised the full, well-informed involvement of indigenous peoples, governments would no longer be able to treat them or their cultural lands as expendable. ${ }^{63}$

\section{References}

Amiott, AJ: 'Environment, Equality, and Indigenous Peoples' Land Rights in the Inter-American Human Rights System: Mayagna (Sumo) Indigenous Community of Awas Tingni v. Nicaragua' Environmental Law 32 (2002), 873-904.

Boadle, A: 'Brazil's Bible, beef and bullets lobby backs Temer, unfazed by scandal'. Reuters, June 24, 2016. Available: www.reuters.com/article/us-brazil-politics-conservatives/brazils-bible-beefand-bullets-lobby-backs-temer-unfazed-by-scandal-idUSKCNOZA2RT (12. 11. 2019.)

Calafate, P: 'The Rights of the Indigenous Peoples of Brazil: Historical Development and Constitutional Acknowledgment'. International Journal on Minority and Group Rights 25, no 2 (2018), 183-209. DOI: 10.1163/15718115-02502004

Caselaw database. ESCR-Net. Available: www.escr-net.org/caselaw/2006/case-mayagna-sumoawas-tingni-community-v-nicaragua-eng (21. 12. 2020.)

Communicades Indigenos da Bacia do Rio Xingu v Brasil (Belo Monte Dam Case). Inter-American Commission on Human Rights Report No 381/10 (I-ACHR, April 1, 2011).

Cunha, MC et al.: 'Indigenous Peoples boxed in by Brazil's political crisis'. HAU Journal of Ethnographic Theory 7, no 2 (2017), 403-426. DOI: 10.14318/hau7.2.033

Demissie, F: African Diaspora in Brazil: History, Culture and Politics. New York, Routledge, 2016. DOI: $10.4324 / 9781315540528$

Guajajara, S: 'The fight to save the Amazon is urgent as there is no Plan B'. Down to Earth, August 28, 2019. Available: www.downtoearth.org.in/blog/forests/-the-fight-to-save-the-amazon-isurgent-as-there-is-no-plan-b-66391 (21. 12. 2020.)

Hohmann, J and M Weller (eds.): The UN Declaration on the Rights of Indigenous Peoples: A Commentary. Oxford, Oxford University Press, 2018.

'ILO Says Brazil Violated Convention 169 in Belo Monte Case. International Labor Organization Confirms Government Violated Indigenous Rights.' State News Service, March 7, 2012. Available: https://link.gale.com/apps/doc/A282433083/ITOF (14. 11. 2019.)

Martha, GB Jr., E Alves, and E Contini: 'Land-saving approaches and beef production growth in Brazil'. Agricultural Systems 110 (2012), 173-177. DOI: 10.1016/j.agsy.2012.03.001

Miki, Y: Frontiers of Citizenship: A Black and Indigenous History of Postcolonial Brazil. Cambridge, Cambridge University Press, 2018. DOI: 10.1017/9781108277778

Monitoring Indigenous and Tribal Peoples' Rights through ILO Conventions: A compilation of ILO supervisory bodies' comments 2009-2010. International Labour Organization. Available: http:// hrbaportal.org/wp-content/files/wcms_126028.pdf (14.11. 2019.)

62 AJ Amiott, 'Environment, Equality, and Indigenous Peoples' Land Rights in the Inter-American Human Rights System: Mayagna (Sumo) Indigenous Community of Awas Tingni v. Nicaragua,' Environmental Law 32 (2002), 903.

63 Ibid. 
Ormaza, MVC: The Requirement of Consultation with Indigenous Peoples in the ILO: Between Normative Flexibility and Institutional Rigidity. The Hague: Brill, 2017.

Phillips, D: 'Bolsonaro to abolish human rights ministry in favour of family values'. The Guardian, December 10, 2018. Available: www.theguardian.com/world/2018/dec/06/ outcry-over-bolsonaros-plan-to-put-conservative-in-charge-of-new-family-and-womenministry (12. 11. 2019.)

Phillips, D: ‘»We are fighting«: Brazil's indigenous groups unite to protect their land'. The Guardian, March 4, 2019. Available: www.theguardian.com/world/2019/mar/04/we-are-fighting-brazilsindigenous-groups-unite-to-protect-their-land (02. 12. 2019.)

Phillips, D: 'Brazil: Indigenous people rally in capital to protest against Bolsonaro onslaught'. The Guardian, April 24, 2019. Available: www.theguardian.com/world/2019/apr/24/brazilindigenous-people-bolsonaro-protest (12.11. 2019.)

Phuong, C: The International Protection of Internally Displaced Persons. Cambridge: Cambridge University Press, 2005. DOI: 10.1017/CBO9780511494062

Pinto, JRS: 'The legislative and public policies in Brazil: before and after the 1988 Constitution'. Journal of Legislative Studies 22, no 4 (2016), 484-505. DOI: 10.1080/13572334.2016.1235335

Ramos, AR: 'The Indigenous Movement in Brazil: A Quarter Century of Ups and Downs. Cultural Survival Quarterly 21, no 2 (1997), 50-53.

Report of the Committee of Experts on the Application of Conventions and Recommendations. International Labour Conference, $98^{\text {th }}$ Session, 2009. Available: www.ilo.org/public/libdoc/ ilo/P/09661/09661(2009-98-1A).pdf (21.12. 2020.)

Report of the Special Rapporteur on the Rights of Indigenous Peoples on her Mission to Brazil. United Nations General Assembly, Available: http://unsr.vtaulicorpuz.org/site/index.php/en/ documents/country-reports/154-report-brazil-2016) (17. 11. 2019.)

Santos, RV et al:: 'The identification of the Indigenous population in Brazil's official statistics, with an emphasis on demographic censuses'. Statistical Journal of the IAOS 35, no 1 (2019), 2946. DOI: $10.3233 / \mathrm{sji}-180471$

Silberling, SL: 'Displacement and quilombos in Alcantara, Brazil: modernity, identity, and place'. International Social Science Journal 55, no 175 (2004), 145-156. DOI: 10.1111/14682451.5501019_13

Valenta, L: 'Disconnect: The 1988 Brazilian Constitution, Customary International Law, and Indigenous Land Rights in Northern Brazil.' Texas International Law Journal 38, no 3 (2003), 643-662.

Watson, F: 'The uncontacted tribes of Brazil face genocide under Jair Bolsonaro'. The Guardian, December 31, 2018. Available: www.theguardian.com/commentisfree/2018/dec/31/tribesbrazil-genocide-jair-bolsonaro (12. 11. 2019.)

Watts, J: 'Dilma Rousseff impeachment: what you need to know - the Guardian briefing' The Guardian, August 31, 2016. Available: www.theguardian.com/news/2016/aug/31/dilmarousseff-impeachment-brazil-what-you-need-to-know (12. 11. 2019.)

\section{Legal sources}

Inter-American Court of Human Rights - The Case of the Mayagna (Sumo) Awas Tingni Community v. Nicaragua - Judgment of August 31, 2001. Available: www.informea.org/sites/default/files/ court-decisions/Mayagna_\%28Sumo\%29_Awas_Tingni_Community_\%20v_Nicaragua.pdf (21. 12. 2020.) 
International Labour Organization (ILO), Indigenous People and Tribal Peoples Convention (adopted June 27, 1989, entered into force September 5, 1991). C169.

Supreme Federal Tribunal of Brazil, Judgement No. 027/2007/JCM/JF/MA (Jurisdicia Federal de 1a Instancia). Available www.ilo.org/wcmsp5/groups/public/--ed_norm/--normes/documents/ publication/wcms_123946.pdf (14.11. 2019.)

UN General Assembly, United Nations Declaration on the Rights of Indigenous Peoples, (adopted October 2, 2007). A/RES/61/295. 